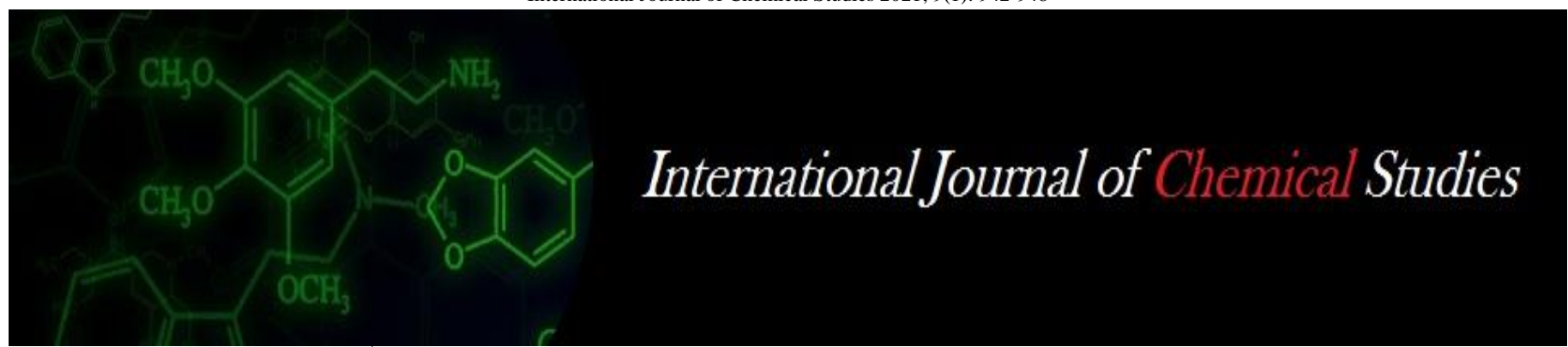

P-ISSN: 2349-8528

E-ISSN: 2321-4902

www.chemijournal.com

IJCS 2021; 9(1): 942-948

(C) 2021 IJCS

Received: 18-10-2020

Accepted: 30-12-2020

Banothu Raveendar

1. College of Fisheries, G B Pant University of Agriculture and Technology Pantnagar, U.S. Nagar, Uttarakhand, India

2. College of Fisheries Science,

Pebbair, Wanaparthy,

Telangana, India

Udai Ram Gurjar

ICAR- Central Institute of

Fisheries Education, Mumbai,

Maharashtra, India

Suman Takar

TNJFU- Fisheries College and

Research Institute,

Thoothukudi, Tamil Nadu, India

Ravi Gugulothu

College of Fisheries Science,

Pebbair, Wanaparthy,

Telangana, India

Shyamprasad Mamidala

College of Fisheries Science,

Pebbair, Wanaparthy,

Telangana, India

Balaji Guguloth

Krishi Vigyan Kendra,

PVNRTVU, Mamnoor,

Warangal (U), Telangana, India

Corresponding Author:

Udai Ram Gurjar

ICAR- Central Institute of

Fisheries Education, Mumbai,

Maharashtra, India

\section{Soil and water characteristics of Nanak Sagar reservoir, Tarai region of Uttarakhand, India}

\author{
Banothu Raveendar, Udai Ram Gurjar, Suman Takar, Ravi Gugulothu, \\ Shyamprasad Mamidala and Balaji Guguloth
}

DOI: https://doi.org/10.22271/chemi.2021.v9.i1m.11349

\begin{abstract}
The present study was directed to assess the Nanak Sagar reservoir's soil and water characteristics, located in the Tarai region of Uttarakhand. Monthly samplings were conducted at three selected sites during August 2016 to March 2017. The catchment area of Nanak Sagar reservoir is mainly silty and loamy. During the study period, the range of variation in water temperature, transparency, electrical conductivity and TDS was recorded as 16.9 to $34^{0} \mathrm{C}, 67.9$ to $155.5 \mathrm{~cm}, 118$ to $336 \mu \mathrm{Scm}^{-1}$ and 91.7 to $156 \mathrm{mg} \mathrm{L}^{-1}$, respectively. The highest values of temperature, transparency, electrical conductivity and TDS were found in the months of September, November, August and August, while the lowest values were recorded in January, August, September and October respectively. Chemical parameters like pH, dissolved oxygen, free $\mathrm{CO} 2$, Alkalinity, Phosphate and Nitrate were found to vary from 7 to 8.7, 3.2 to $9.6 \mathrm{mg} \mathrm{L}^{-1}, 0$ to $6 \mathrm{mg} \mathrm{L}^{-1}, 60$ to $140 \mathrm{mg} \mathrm{L}^{-1}, 0.043$ to $0.2 \mathrm{mg} \mathrm{L}^{-1}$ and 0.224 to $0.64 \mathrm{mg} \mathrm{L}^{-1}$ respectively. The highest and lowest values of $\mathrm{pH}$, dissolved oxygen, free $\mathrm{CO} 2$, total Alkalinity, Phosphate and Nitrate were recorded in the month of January, February, August, February, September while lowest values were recorded in the month of August, September, March, August and March respectively. The reservoir's water quality is within normal condition so fish production from the reservoir could be increased.
\end{abstract}

Keywords: Tarai region, Nanak Sagar, chemical parameter, catchment area

\section{Introduction}

A large number of rivers are originated in the Siwalik Hills, which enter into and flow through the Tarai region of Uttarakhand. Consequently, several reservoirs have been constructed on the rivers during post independent period primarily for irrigation purpose. The Nanak Sagar reservoir was constructed in the year 1962 near the town Sitarganj across the river Deoha. The dam's goal was to accumulate water during monsoon and feed the Sarda Canal system during Rabi season. Now it is used for fish production also and the irrigation potential of this dam is 39200 hectares. The basin of the Nanak sagar reservoir falls under the influence of south west monsoon. The rivers experience heavy floods from July to the end of September. Since the area does not lie in Snow Belt, the rivers remain almost dry in the remaining part of the year. The north area of the reservoir is also covered with thick and reserved forest. The climate of the reservoir is hot and humid. The Tarai region of the Uttrakhand has many small ( $<1000$ ha) and medium sized (1000-5000 ha) reservoirs like Nanak Sagar, Sarda Sagar, Dhaura, Haripura, Baigul, Baur and Tumaria ${ }^{[1]}$. Among these reservoirs, Nanak Sagar is the largest one with a total water surface area of 4900 ha ${ }^{[2]}$. The commercial fishing in the Nanak Sagar reservoir is carried out using traditional gears viz. gill net, triangular net, drag net, hooks and lines, cast net and rod and line. To harvest the fishes from Nanak Sagar gill net was commonly used [3]. The Nanak Sagar reservoir's floristic composition contained 23 phytoplankton taxa and 14 zooplankton taxa ${ }^{[4]}$. Nanak Sagar reservoir has a rich assemblage of naturally occurring fish species. The Nanak Sagar reservoir's fish fauna comprises 30 species belonging to 7 different orders, 9 families and 22 genera of minor carps, major carps, weed fishes and catfishes/carnivorous fishes ${ }^{[5]}$. An aquatic ecosystem's health is determined by various limnological characteristics of water ${ }^{[6,7]}$. The major factors which affect the biological productivity of a water body can be broadly put into three categories viz. Climatic, morphometric and edaphic ${ }^{[8]}$. Reservoirs located at different latitudes and longitudes differ in the amount of available incident light energy and rainfall. 
The wind is another important climatic factor that has significant implication on the aquatic biotope's thermal features and helps distribute heat. The extent of drainage area and its erosion rate and total runoff determine the nutrient load into the reservoir. Soil basin quality influences the reservoir productivity to a great extent. The fertility of the reservoirs is dependent more on the nature of the catchment area than on the basin soil ${ }^{[9]}$. Area, mean depth and shore development index are other important morphometric factors determining the productivity of large water bodies. Among the chemical parameters, $\mathrm{pH}$, total alkalinity, dissolved oxygen, carbon dioxide and calcium, magnesium, silicate, chloride, nitrate, phosphate, total dissolved solids etc. are often used as indices of fish productivity ${ }^{[10,11]}$.

Therefore, present study was conducted on soil and water aspects of Nanak Sagar reservoir in Tarai region of Uttarakhand, India. This study will help in assessing the current quality of soil and water which is convenient way for the sustainable fisheries management in the reservoir.

\section{Materials and Methods}

\section{Study area and sampling stations}

The reservoir is situated at latitude of $79^{\circ}, 50^{\prime}, 34^{\prime \prime}$ E, 28, 57, 20 'N near Sitarganj. The salient features of Nanak Sagar dam and reservoir are given in the Table 1 . For the present study, three different reservoir sites (S1, S2 \& S3) were selected for steady sampling of limnological parameters. Site $\mathrm{S} 1$ in Nanak Sagar Dam is the Baoli Sahib, it is about one and a half km away from holly Gurudwara Nanakmatta Sahib. Generally, this place is also used as a Boat stand, so daily number of people come here. Another site is S2, known as Kati pulia which is about $500 \mathrm{~m}$ away from the first site and has a small drainage for agriculture. The last site was the Dam area (S3) which is about $500 \mathrm{~m}$ from site $\mathrm{S} 2$ and $1000 \mathrm{~m}$ from site $\mathrm{S} 1$.

\section{Soil Sampling}

The soil samples were collected from the selected site of the reservoir bed with the help of dredge. Subsequently, the samples were air dried ground to fine powder, sieved through $2 \mathrm{~mm}$ sieve and analyzed for soil texture, soil $\mathrm{pH}$, organic carbon, available nitrogen, available phosphorus and available potassium as per methods described by Sharma ${ }^{[12]}$.

\section{Water Sampling}

Water samples were collected fortnightly from the three sampling stations to obtain various physico-chemical parameters of the Nanak Sagar reservoir. Sampling was done during day time (8-10.30 A.M.) from the selected sites. Some of the physico-chemical parameters were analyzed on the spot while samples for remaining water quality parameters were brought to the research laboratory of Aquatic Environment Management Department at College of Fisheries, GBPUAT, Pantnagar under standard conditions for analyses ${ }^{[13]}$. The observed values of soil and water parameters was subjected to statistical analysis.

Table 1: Geomorphological and hydrographic features of Nanak Sagar reservoir

\begin{tabular}{|c|c|}
\hline Year of commencement & 1956 \\
\hline Year of completion & 1962 \\
\hline Name of River & Deoha \\
\hline Dist. & U.S. Nagar \\
\hline Latitude & $28^{0} 45^{\prime} \mathrm{N}$ \\
\hline Longitude & $79^{0} 45^{\prime} \mathrm{E}$ \\
\hline Altitude & $200 \mathrm{~m}$ \\
\hline Maximum depth & $20 \mathrm{~m}$ \\
\hline Mean depth & $10 \mathrm{~m}$ \\
\hline Type of Dam & Earthen \\
\hline Maximum height of Dam & $16.50 \mathrm{~m}(54 \mathrm{Ft})$. \\
\hline Length of Dam & East Wing $-10.6 \mathrm{~km}$, West Wing $-08.6 \mathrm{~km}$ \\
\hline Catchment Area & $570 \mathrm{~km}^{2}$ \\
\hline Annual average Rainfall & $1665 \mathrm{~mm}$ \\
\hline Normal storage level & $214.27 \mathrm{~m}(703 \mathrm{Ft})$. \\
\hline Maximum storage level & $215.19 \mathrm{~m}(706 \mathrm{Ft})$. \\
\hline Dead storage level & $207.30 \mathrm{~m}$ (680 Ft.) \\
\hline Reservoir level at designed flood & $215.95 \mathrm{~m}(708.50 \mathrm{Ft})$. \\
\hline Free board & $1.81 \mathrm{~m}(6.0 \mathrm{Ft})$. \\
\hline Max. height of wave splash & $1.50 \mathrm{~m}$ \\
\hline Seismic Intensity & 0.232 \\
\hline Crest level & $207.30 \mathrm{~m}(680 \mathrm{Ft})$. \\
\hline Crest length & $7 \times 6.10 \mathrm{~m}(7 \mathrm{x} 20 \mathrm{Ft})$. \\
\hline Top elevation of Dam & $217.02 \mathrm{~m}(712.0 \mathrm{Ft})$. \\
\hline Top width of Dam & $6 \mathrm{~m}(20 \mathrm{Ft})$. \\
\hline Purpose of Dam & Irrigation and flood control \\
\hline Gross Capacity at FRL & 209.08 M.C.M (169500 AC Ft.) \\
\hline
\end{tabular}

\section{Results and Discussion \\ Soil Characteristics}

The results of soil analysis of Nanak Sagar reservoir is presented in Table 2. The catchment area of Nanak Sagar reservoir is mainly silty and loamy in nature. Such a characteristic silt-loam type of sediments was prevalent in the valley lakes of Kashmir where silt-loam sediment originates from deposition of autochthonous and allochthonous particulate matter in the basin ${ }^{[14]}$. The bottom soil of the Nanak Sagar reservoir is the same as the soil of valley lake basins due to its high sand, silt and clay. The moderately alkaline nature of the basin soil ( $\mathrm{pH} 7.2$ to 7.4) is good for fish production ${ }^{[10]}$. In Nanak Sagar reservoir the lower and higher $\mathrm{pH}$ values are 7.88 and 8.1 respectively. Similar findings were also recorded by Sengar et al. (2015) ${ }^{[15]}$. The aquatic soil having low level of organic carbon $(<0.5 \%)$ 
result into low productivity while productivity is moderately high if the carbon level fluctuates between 0.5 and $1.5 \%$, but it is maximal if the carbon levels are high (1.5 to $2.5 \%)^{[16]}$. Nanaksagar had moderate concentration of soil organic carbon (0.99 to $1.55 \%)$. Thus, this reservoir appears to be moderately productive. The low content of nitrogen $(<25$ $\mathrm{mg} / 100 \mathrm{~g}$ soil) in bottom soils are responsible for poor reservoir productivity while it slightly higher $(25$ to $75 \mathrm{mg}$ / $100 \mathrm{~g}$ ) concentration shows moderate production and the higher level of nitrogen (above $75 \mathrm{mg} / 100 \mathrm{~g}$ soil) gives fairly high production ${ }^{[16]}$. The available nitrogen level in Nanak Sagar reservoir (26.8 to $29.9 \mathrm{mg} / 100 \mathrm{~g}$ soil) can be categorized as average. The available phosphorous content of less than $3 \mathrm{mg} / 100 \mathrm{~g}$ soil, $3-6 \mathrm{mg} / 100 \mathrm{~g}$ soil and $>6 \mathrm{mg} / 100 \mathrm{~g}$ soil are indicative of poor, moderate and high fish productivity, respectively ${ }^{[12,16]}$. The phosphorous content in Nanak Sagar reservoir ranging between $2.16-2.52 \mathrm{mg} / 100 \mathrm{~g}$ soil represents low productive water bodies with respect to fish production. The level of available potassium ranged from 23.62 to $26.51 \mathrm{mg} / 100 \mathrm{~g}$ soil. If the water bodies having non absorptive soil are usually poor in potassium ${ }^{[10]}$. Golterman suggested that submerged weed infested water bodies have low potassium contents ${ }^{[17]}$, which may be one of the reasons for low potassium content in this reservoir because Nanak Sagar reservoir is infested with $90 \%$ of submerged weeds, which is creating a problem in netting.

Table 2: Soil characteristics of Nanak Sagar reservoir

\begin{tabular}{|c|c|c|c|}
\hline Parameters & Site - 1 & Site - 2 & Site - 3 \\
\hline Soil composition (\%) & & & \\
\hline Sand & 48.2 & 49.9 & 49.89 \\
\hline Silt & 24.1 & 23.5 & 24.75 \\
\hline Clay & 27.7 & 26.6 & 25.36 \\
\hline pH & 8.1 & 8.01 & 7.88 \\
\hline Organic carbon (\%) & 1.55 & 0.99 & 1.29 \\
\hline Available nitrogen (mg/ 100g soil) & 29.9 & 26.8 & 28.5 \\
\hline Available phosphorus (mg/ 100g soil) & 2.52 & 2.16 & 2.34 \\
\hline Available potassium (mg/ 100g soil) & 26.51 & 23.62 & 25.31 \\
\hline
\end{tabular}

\section{Physical characteristics of water}

The limnological profile of the Nanak Sagar reservoir is highly influenced by climate change and intensive human activities. Physical parameters like temperature, conductivity and TDS are known to operate aquatic ecosystem ${ }^{[18]}$.

\section{Water temperature}

The data on the monthly variation in water temperature of different Nanak Sagar reservoir sites is presented in Fig. 1. The range of water temperature during the study period varied from $16.9{ }^{\circ} \mathrm{C}$ to $34{ }^{0} \mathrm{C}$. The lowest water temperature was recorded in January i.e. $17.9{ }^{0} \mathrm{C}, 16.9{ }^{0} \mathrm{C}, 17.5{ }^{\circ} \mathrm{C}$ while the highest temperature was recorded in September i.e. $34{ }^{\circ} \mathrm{C}, 33$ ${ }^{0} \mathrm{C}$ and $33.5{ }^{0} \mathrm{C}$ at sites $\mathrm{S} 1, \mathrm{~S} 2$ and $\mathrm{S} 3$, respectively. The average water temperatures at three sampling sites were 26.4 ${ }^{0} \mathrm{C}, 25.8{ }^{0} \mathrm{C}$ and $25.9{ }^{0} \mathrm{C}$, respectively. A decreasing trend of water temperature can be seen from October, 2016 to January, 2017 , followed by an increasing pattern with the onset of February.

The optimum temperature of water for fishe's growth and survival is between $26-32{ }^{0} \mathrm{C}{ }^{[19]}$. The maximum water temperature was $34{ }^{\circ} \mathrm{C}$ at site 1 in monsoon season may be due to high suspended particles found in these site having property in water column to absorb and scatter sunlight and hence determine the extinction of solar radiation and minimum was found $\left(16.9{ }^{\circ} \mathrm{C}\right)$ in site 2 at post monsoon season could be due to water coming from high altitude region. The average temperature of Tarai reservoirs always remains above $20{ }^{\circ} \mathrm{C}$ and is suitable to harbor all the tropical fishes ${ }^{[20]}$. Nandakishor et al. (2016) ${ }^{[21]}$ also done similar research and result supports the findings of present research and even similar patterns of water temperature variation have been described by Rawat ${ }^{[22]}$ and Mishra et al. (2017) ${ }^{[23]}$.

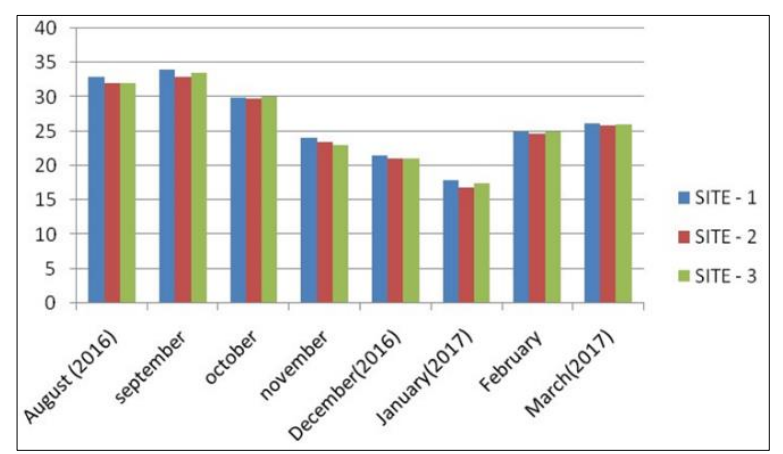

Fig 1: Monthly variation of temperature $\left({ }^{0} \mathrm{C}\right)$ at the selected sites of Nanak Sagar Reservoir

\section{Transparency}

Monthly records of changes in the water sample's transparency of three different sites in the Nanak Sagar reservoir are presented in Fig. 2. The highest transparency was recorded during November i.e. $187.7 \mathrm{~cm}, 194.7 \mathrm{~cm}$ and $190.5 \mathrm{~cm}$ at sites $\mathrm{S} 1, \mathrm{~S} 2$ and $\mathrm{S} 3$ respectively. The lowest transparency was recorded during the month of August i.e. $67.9 \mathrm{~cm}, 72.5 \mathrm{~cm}$ and $68 \mathrm{~cm}$ at sites $\mathrm{S} 1, \mathrm{~S} 2$ and $\mathrm{S} 3$ respectively. The maximum average value was recorded $(190.9 \mathrm{~cm})$ in the month of November and minimum value was recorded $(69.4 \mathrm{~cm})$ in the August.

There is a seasonal variation of water transparency due to the differential amounts of suspended solids, algae, silt and illumination ${ }^{[12,23]}$. Low values of water transparency during the monsoon season are caused by large amount of silt being supplied into the reservoirs through catchment area ${ }^{[24]}$. The transparency range varied from 67.9 to $194.7 \mathrm{~cm}$; low value in the site $\mathrm{S} 1(67.9 \mathrm{~cm})$ during monsoon season may be due to high load of suspended solids and agriculture runoff. The high value in the site $\mathrm{S} 2(194.7 \mathrm{~cm})$ was found during post monsoon due to the settlement of suspended solids in this site compared to other sites, resulting in high transparency. Mishra et al. (2017) ${ }^{[23]}$ reported that water transparency ranged between $230 \mathrm{~cm}$ in March and to $36 \mathrm{~cm}$ in May at Dhaura and Baigul, the two medium reservoirs of Uttarakhand, India. Ananya et al. (2016) ${ }^{[25]}$ reported that water transparency ranged between $15 \mathrm{~cm}$ in monsoon to 202 $\mathrm{cm}$ in pre monsoon season at Sarni Reservoir, Madhya Pradesh.

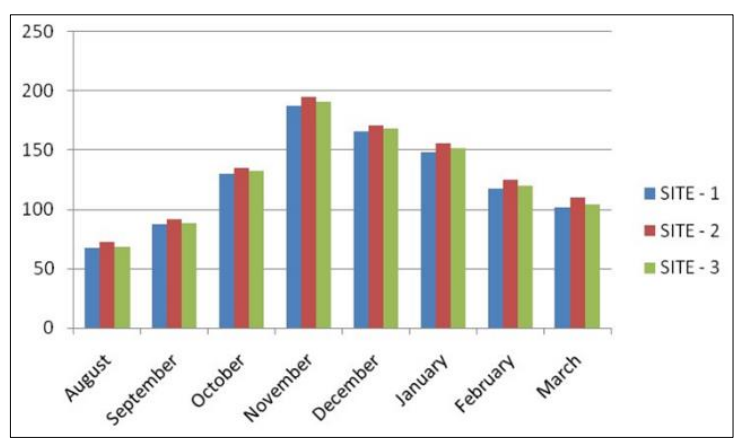

Fig 2: Monthly variation of transparency $(\mathrm{cm})$ at the selected sites of Nanak Sagar Reservoir 


\section{Specific conductivity (EC)}

Electrical conductivity of water samples of three different Nanak Sagar reservoir sites was observed monthly and presented in Fig. 3. The Specific conductivity of water is a measure of the resistance of a solution to electrical flow, which increase with increasing of ion content ${ }^{[26]}$. The total amount of salts determine the conductivity in waters. The lowest electrical conductivity $221 \mu \mathrm{Scm}^{-1}, 119 \mu \mathrm{Scm}^{-1}$ and $118 \mu \mathrm{Scm}^{-1}$ was recorded in the month of September at sites S1, S2 and S3, respectively. The highest electrical conductivity $320 \mu \mathrm{Scm}^{-1}, 316 \mu \mathrm{Scm}^{-1}$ and $326 \mu \mathrm{Scm}^{-1}$ recorded in the month of March at sites S1, S2 and S3, respectively. The maximum average value was recorded in the month of March $\left(320 \mu \mathrm{Scm}^{-1}\right)$ and minimum value in September $\left(152.6 \mu \mathrm{Scm}^{-1}\right)$. With decreasing water level and increased wind velocity, concentration of salts increases, resulting in the simultaneous increase of conductivity which was similar to findings of earlier investigations ${ }^{[21,25]}$.

Olsen classified water bodies having conductivity values greater than $500 \mu \mathrm{Scm}^{-1}$ as eutrophic ${ }^{[27]}$. According to this criterion, Nanak Sagar reservoir falls under the category of mesotrophic. Therefore, there is enough scope for increasing fish production.

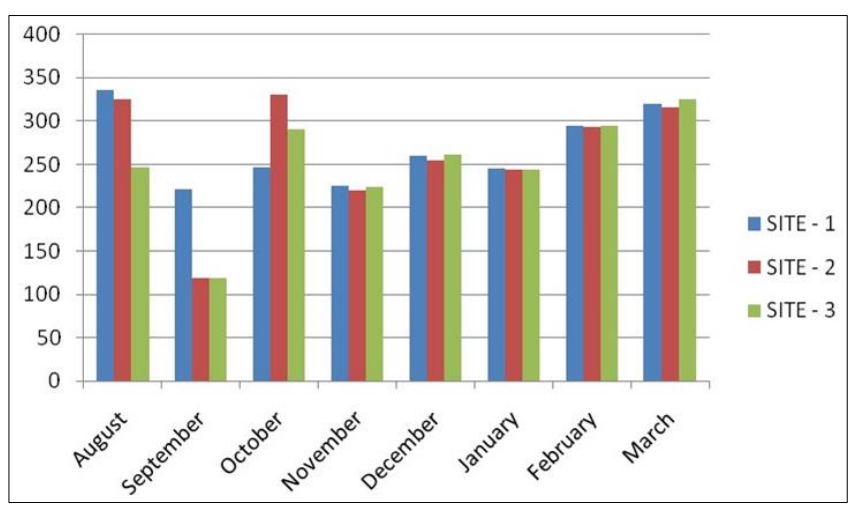

Fig 3: Monthly variation of $\mathrm{EC}\left(\mu \mathrm{Scm}^{-1}\right)$ at the selected sites of Nanak Sagar Reservoir

\section{Total dissolved solids (TDS)}

Monthly changes in total dissolved solids of water samples of three different sites were recorded which is presented in Fig. 4. The highest total dissolved solids were recorded during August i.e. $156 \mathrm{mg} \mathrm{L}^{-1}, 138 \mathrm{mg} \mathrm{L}^{-1}$ and $142 \mathrm{mg} \mathrm{L}^{-1}$ at sites S1, S2 and S3, respectively. The lowest total dissolved solids were recorded during month of February $92.5 \mathrm{mg} \mathrm{L}^{-1}, 91.7$ $\mathrm{mg} \mathrm{L}^{-1}$ and $92 \mathrm{mg} \mathrm{L}^{-1}$ at sites S1, S2 and S3, respectively. The maximum average value was recorded in the month of August $\left(156 \mathrm{mg} \mathrm{L}^{-1}\right)$ and a minimum average value was recorded in the month of February $\left(92.06 \mathrm{mg} \mathrm{L}^{-1}\right)$.

The concentration of total dissolved solids has been considered an index of productivity of the aquatic environments ${ }^{[10]}$. Rawat (1991) ${ }^{[22]}$ has observed a significant relationship between total dissolved solids and quantities of plankton, bottom fauna and fish fauna. Seasonal fluctuations in the total solids are mainly due to the variations in the ionic composition of water. The maximum average TDS value was recorded in the month of August (156 mg L $\left.\mathrm{m}^{-1}\right)$, it may be because of high load of suspended solid from the catchment area and the minimum TDS value recorded in February (92.06 $\mathrm{mg} \mathrm{L}^{-1}$ ), might be due to the settlement of dissolved solids in deep and stagnant water. TDS is generally high during monsoon season due to flooding and the entry of allochthonous materials from the catchment area.
The concentration of dissolved solids is an essential parameter of drinking water and other quality standards. The permissible limit of TDS is up to $500 \mathrm{mg} \mathrm{L}^{-1}$ [28]. TDS levels are also influenced by other parameters like water $\mathrm{pH}$ and temperature. Increased TDS concentration in the aquatic medium disturbs the ecological balance by causing suffocation of aquatic fauna ${ }^{[29]}$.

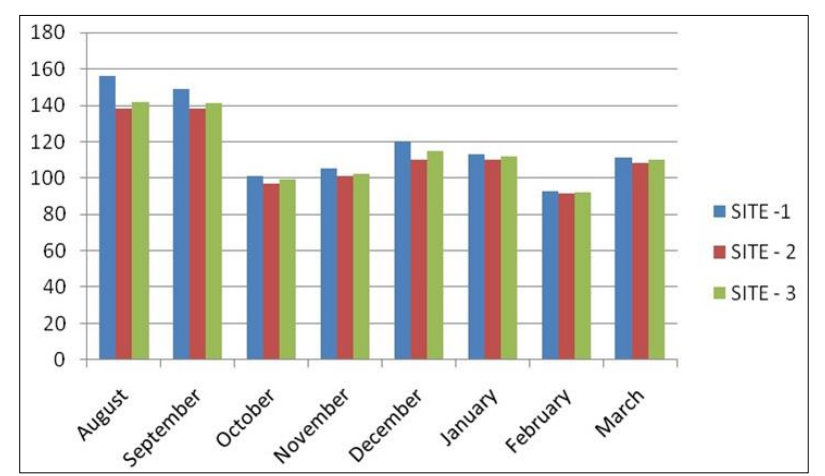

Fig 4: Monthly variation of TDS $\left(\mathrm{mg} \mathrm{L}^{-1}\right)$ at the selected sites of Nanak Sagar Reservoir

\section{Chemical characteristics of water \\ pH}

A monthly record of changes in $\mathrm{pH}$ of water samples at three different sites in Nanak Sagar reservoir is presented in Fig. 5. The $\mathrm{pH}$ of reservoir water is an important general water quality indicator as it acts as a major factor in most chemical and biological reactions. The range of $\mathrm{pH}$ in Nanak Sagar reservoir during the study period was between 7 to 8.7. The highest value of $\mathrm{pH}$ recorded in the investigation period was $8.7,8.3$ and 8.6 at sites S1, S2 and S3, respectively in the month of January while the lowest in the month of March i.e. 7.4, 7.2 and 7.3 at sites S1, S2 and S3, respectively.

The low $\mathrm{pH}$ observed during monsoon season (August) was owing to increased dilution of water and decomposition of the greater quantity of the added organic matter, whereas higher $\mathrm{pH}$ value during winter (January) may be due to increased photosynthesis. The large amounts of organic acids are liberated during decomposition, which lowers the $\mathrm{pH}$ of water bodies ${ }^{[30,31]}$. Das (1961) ${ }^{[32]}$ and Mishra et al. (2003) ${ }^{[33]}$ have reported that a pH range of 7.2 to 8.5 favours plankton growth. $\mathrm{pH}$ values above 9.0 are not conducive for plankton and fish production ${ }^{[12]}$. Sreenivasan (1978) ${ }^{[34]}$ and Jhingran (1991) ${ }^{[10]}$ have also suggested that the reservoir's moderately alkaline nature is favourable for fish production. The majority of Indian reservoirs have moderately alkaline $\mathrm{pH}{ }^{[35]}$. Thus, Nanak Sagar reservoir with a favourable $\mathrm{pH}$ regime is suitable for fish growth.

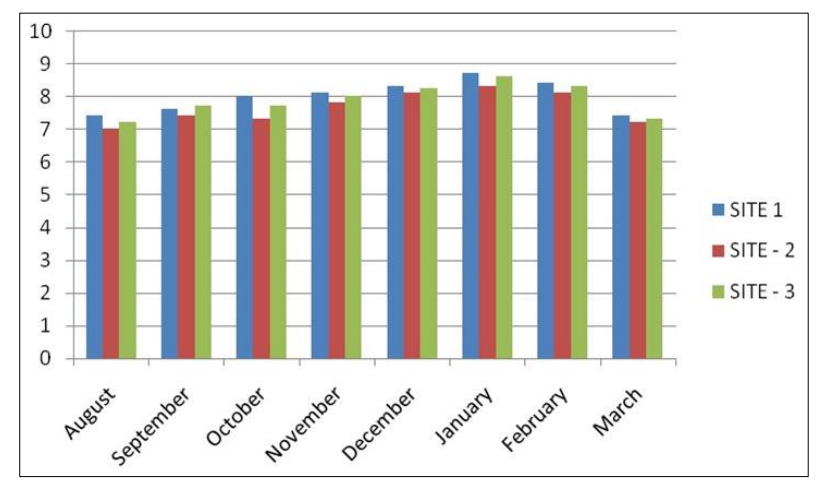

Fig 5: Monthly variation of $\mathrm{pH}$ at the selected sites of Nanak Sagar Reservoir 


\section{Dissolved oxygen}

The dissolved oxygen concentration of water samples of three different sites of the Nanak Sagar reservoir is given in Fig. 6. The dissolved oxygen (DO) of reservoirs is a very important indicator for determining the condition of a reservoir.

The average values of DO at the three selected sites of Nanak Sagar S1, S2 and S3 were $6.71 \mathrm{mg} \mathrm{L}^{-1}, 7.38 \mathrm{mg} \mathrm{L}^{-1}$ and 6.97 $\mathrm{mg} \mathrm{L}^{-1}$, respectively. The highest value of DO was found in the month of February $9.5 \mathrm{mg} \mathrm{L}^{-1}, 9.6 \mathrm{mg} \mathrm{L}^{-1}$ and $9.5 \mathrm{mg} \mathrm{L}^{-1}$ at the sites S1, S2 and S3, respectively. The lowest DO was observed in the month of September and the values were 3.2 $\mathrm{mg} \mathrm{L}^{-1}, 5.8 \mathrm{mg} \mathrm{L}^{-1}$ and $5.6 \mathrm{mg} \mathrm{L}^{-1}$ at the sites $\mathrm{S} 1, \mathrm{~S} 2$ and $\mathrm{S} 3$, respectively. The higher concentrations of dissolved oxygen during winters were obtained probably due to low water temperature, low turbidity, and increased photosynthetic activity of the green algae found attached on submerged stones, pebbles and water. With the progress of summer, the dissolved oxygen content is decreased in river water due to increase in temperature this is because of low solubility of gases at a higher temperature ${ }^{[36]}$. The increased concentration of dissolved oxygen during February might be due to an increased photosynthesis rate through high aquatic vegetation, algal growth and moderate temperature. The same trend was also found by Rawat (1991) [22], Mishra et al. (2003) [33], Ananya at al. (2016) ${ }^{[25]}$ and Mishra et al. (2017) ${ }^{[23]}$ in their studies. Wide fluctuation in dissolved oxygen content of water in the lakes might be due to dense aquatic vegetation, shallow water depth and intense anthropogenic activities ${ }^{[37]}$.

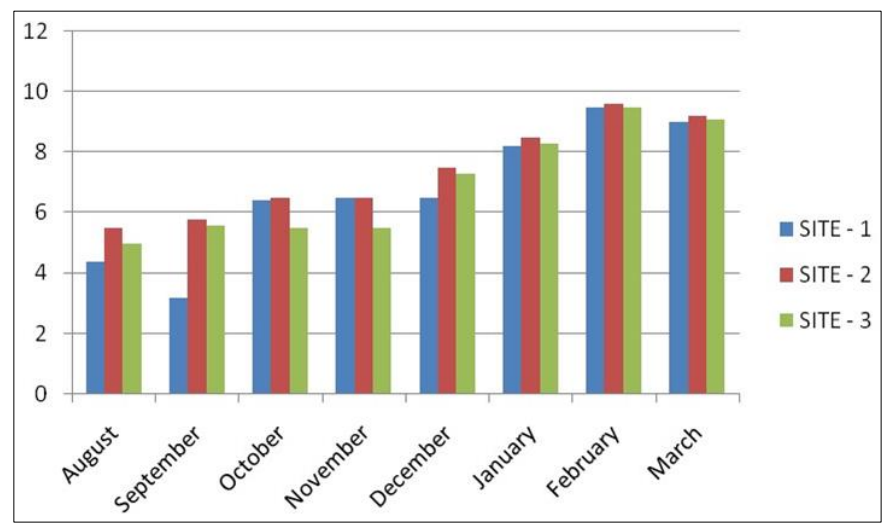

Fig 6: Monthly variation of DO $\left(\mathrm{mg} \mathrm{L}^{-1}\right)$ at the selected sites of Nanak Sagar Reservoir

\section{Free carbon dioxide}

Fig. 7 gives the seasonal fluctuations of free $\mathrm{CO}_{2}$ in Nanak Sagar reservoir. Carbon dioxide is the end product of the degradation of organic carbon in almost all aquatic environments and its variation is sometimes a measure of net ecosystem metabolism ${ }^{[38,39]}$. The highest value of $\mathrm{CO}_{2}$ was recorded in the month of August and the values were $6 \mathrm{mg} \mathrm{L}$ 1, $3 \mathrm{mg} \mathrm{L}^{-1}$ and $4.5 \mathrm{mg} \mathrm{L}^{-1}$ at the sites $\mathrm{S} 1, \mathrm{~S} 2$ and $\mathrm{S} 3$, respectively. The lowest $\mathrm{CO}_{2}$ was observed in the month of March and the values of $0 \mathrm{mg} \mathrm{L}^{-1}$ at all sites, respectively. High concentration of $\mathrm{CO}_{2}$, i.e., $4.5 \mathrm{mg} \mathrm{L}^{-1}$ was recorded in August (monsoon) due to the respiration of organisms and the absence of photosynthetic activity down to cloudy weather ${ }^{[40,}$ ${ }^{41]}$. Absence of $\mathrm{CO}_{2}\left(0 / 0.1 \mathrm{mg} \mathrm{L}^{-1}\right)$ in March and February months may be due to high utilization by aquatic weed and algae during photosynthesis. Similar findings were also recorded by Ananya et al. (2016) ${ }^{[25]}$, Mishra et al. (2017) [23] and Nandkishor et al. (2016) ${ }^{[21]}$.

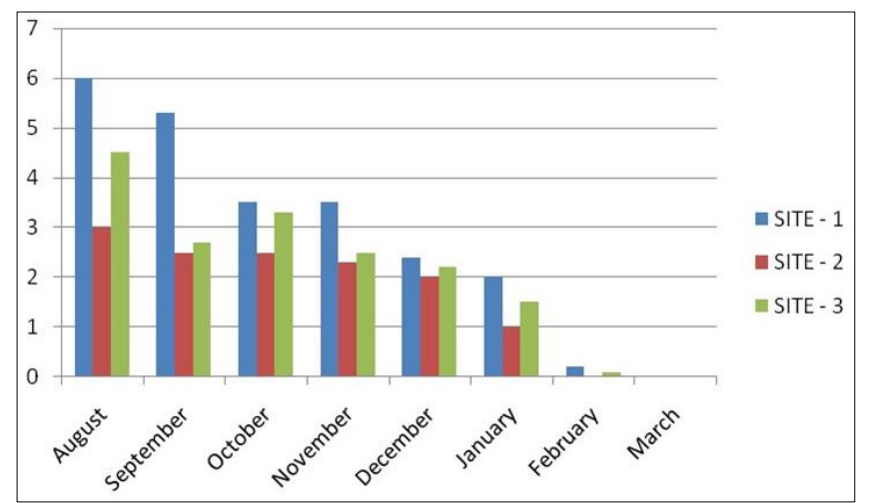

Fig 7: Monthly variation of $\mathrm{CO}_{2}\left(\mathrm{mg} \mathrm{L}^{-1}\right)$ at the selected sites of Nanak Sagar Reservoir

\section{Total alkalinity}

The data on total alkalinity of water samples of three different sites of Nanak Sagar reservoir is given in Fig. 8. The highest value of total alkalinity was found in the month of February with values of $140 \mathrm{mg} \mathrm{L}^{-1}, 136 \mathrm{mg} \mathrm{L}^{-1}$ and $138.5 \mathrm{mg} \mathrm{L}^{-1}$ at the sites S1, S2 and S3, respectively. The lowest value was observed in the month of August and the values were $65 \mathrm{mg}$ $\mathrm{L}^{-1}, 60 \mathrm{mg} \mathrm{L}^{-1}$ and $62 \mathrm{mg} \mathrm{L}^{-1}$ at the sites $\mathrm{S} 1, \mathrm{~S} 2$ and $\mathrm{S} 3$, respectively. The average values of total alkalinity at sites $S 1$, $\mathrm{S} 2$ and $\mathrm{S} 3$ were $97.5 \mathrm{mg} \mathrm{L}^{-1}, 92.68 \mathrm{mg} \mathrm{L}^{-1}$ and $94.25 \mathrm{mg} \mathrm{L}^{-1}$, respectively. The total alkalinity ranged from 62 to $140 \mathrm{mg} / \mathrm{l}$, making the reservoir nutrient rich and highly productive water body. In the present study, the low level alkalinity $\left(62 \mathrm{mg} \mathrm{L}^{-1}\right)$ during August (monsoon season), might be due to quick dilution of alkaline soil [35]. During the month of February (140 mg L-1), the highest total alkalinity may be due to a shallow area and increased the rate of organic decomposition and evaporation of water. The annual average total alkalinity was $112.78 \mathrm{mg} \mathrm{L}^{-1}$. Alkalinity also depends on upon nature of bottom deposits ${ }^{[42]}$. On the other hands a similar trend was also observed in earlier studies ${ }^{[21,23,25]}$.

The natural alkalinity of water depends mainly on salts of weak acids such as carbonates, bicarbonates, borates, silicates, phosphates and the salts of humic acid ${ }^{[43]}$. The carbonates and bicarbonates are largely predominant ions in most of the freshwaters of world [10, 44]. The presence of carbonates in water bodies is chiefly due to phytoplankton which removes half bound $\mathrm{CO}_{2}$ from the bicarbonates and from carbonates.

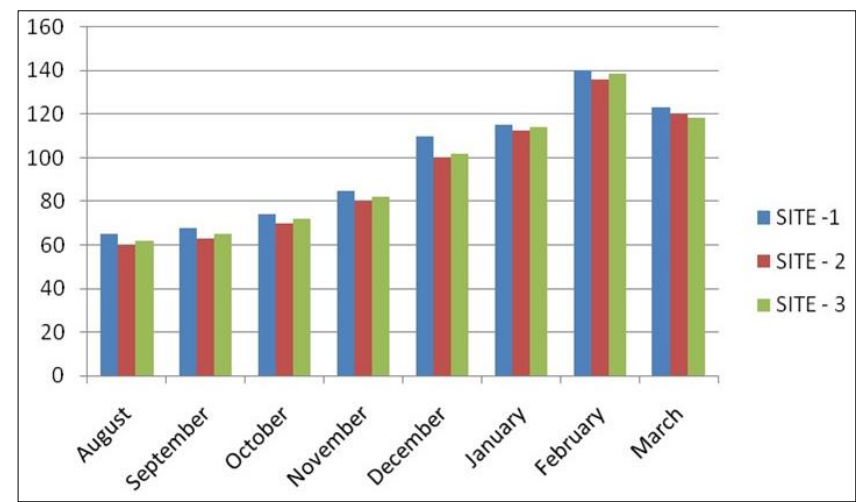

Fig 8: Monthly variation of Alkalinity $\left(\mathrm{mg} \mathrm{L}^{-1}\right)$ at the selected sites of Nanak Sagar Reservoir

\section{Phosphate- phosphorus}

A monthly record on changes in phosphate of water sample at 
three different sites in Nanak Sagar reservoir is presented in Fig. 9. The range of phosphate during the study period varied between $0.043 \mathrm{mg} \mathrm{L}^{-1}$ to $0.2 \mathrm{mg} \mathrm{L}^{-1}$. The highest value of phosphate recorded in the investigation period were $0.2 \mathrm{mg} \mathrm{L}^{-}$ ${ }^{1}, 0.178 \mathrm{mg} \mathrm{L}^{-1}$ and $0.18 \mathrm{mg} \mathrm{L}^{-1}$ at sites $\mathrm{S} 1, \mathrm{~S} 2$ and $\mathrm{S} 3$, respectively in the month of September while lowest in month of March i.e. $0.047 \mathrm{mg} \mathrm{L}^{-1}, 0.043$ and $0.045 \mathrm{mg} \mathrm{L}^{-1}$ at sites $\mathrm{S} 1, \mathrm{~S} 2$ and $\mathrm{S} 3$, respectively. The maximum value estimated in the month of September $\left(0.2 \mathrm{mg} \mathrm{L}^{-1}\right)$ during monsoon may be due to fast assorted agricultural runoff, reduced assimilation in photosynthesis and minimum in the month of March (0.043 $\mathrm{mg} \mathrm{L}^{-1}$ ) during post monsoon may be due to high utilization by phytoplankton community and low silted water. Our findings are supported by research findings of Ananya et al., (2016) ${ }^{[25]}$ and Nandkishore et al., (2016) ${ }^{[21]}$.

The phosphorus to be the most important nutrient for the productivity in aquatic ecosystem ${ }^{[12]}$. Phosphorus in nature generally occurs in very small quantity, but is not the only single critical factor in maintaining the production functions [10]. Only few sources of phosphate occur naturally, major sources of their presence in water body are domestic waste, detergent and agriculture run-off containing fertilizer ${ }^{[45]}$. The phosphate content changes appeared to follow the trends of nitrate though the level of phosphate was poor compared to nitrate.

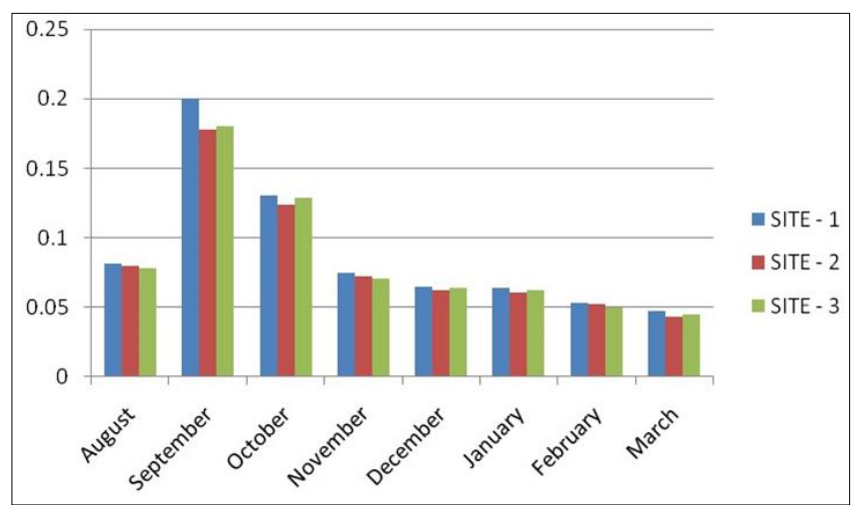

Fig 9: Monthly variation of Phosphate $\left(\mathrm{mg} \mathrm{L}^{-1}\right)$ at the selected sites of Nanak Sagar Reservoir

\section{Nitrate nitrogen}

The data of Nitrate nitrogen concentration of water samples of three different sites of Nanak Sagar reservoir is given in Fig. 10 . The average values of nitrate nitrogen at the three selected sites of Nanak Sagar reservoir S1, S2 and S3 were $0.39 \mathrm{mg} \mathrm{L}$ $1,0.36 \mathrm{mg} \mathrm{L}^{-1}$ and $0.37 \mathrm{mg} \mathrm{L}^{-1}$ respectively. The highest value of nitrate nitrogen was found in the month of September and the values were $0.64 \mathrm{mg} \mathrm{L}^{-1}, 0.6 \mathrm{mg} \mathrm{L}^{-1}$ and $0.62 \mathrm{mg} \mathrm{L}^{-1}$ at the sites $\mathrm{S} 1, \mathrm{~S} 2$ and $\mathrm{S} 3$, respectively. The lowest nitrate nitrogen was observed in the month of March and the values were 0.23 $\mathrm{mg} \mathrm{L}^{-1}, 0.224 \mathrm{mg} \mathrm{L}^{-1}$ and $0.238 \mathrm{mg} \mathrm{L}^{-1}$ at the sites $\mathrm{S} 1, \mathrm{~S} 2$ and $\mathrm{S} 3$, respectively. It was maximum in the month of September ( $\left.0.64 \mathrm{mg} \mathrm{L}^{-1}\right)$ during monsoon season which may be primarily due to agricultural runoff, which is also a rich source of nitrogen applied as fertilizer and the inflow of allochthonous organic matter through river drainage. The minimum value of nitrate was observed in March $(0.224 \mathrm{mg} \mathrm{L}-1)$ may because of high utilization by algal groups and a low source of formation. It may also be the beginning of the stratification cycle, the phytoplankton community was mainly using nitrate as nitrogen source ${ }^{[46]}$. These results are supported by observations made by Ananya et al., (2016) ${ }^{[25]}$ and Nandkishore et al., (2017) ${ }^{[21]}$.

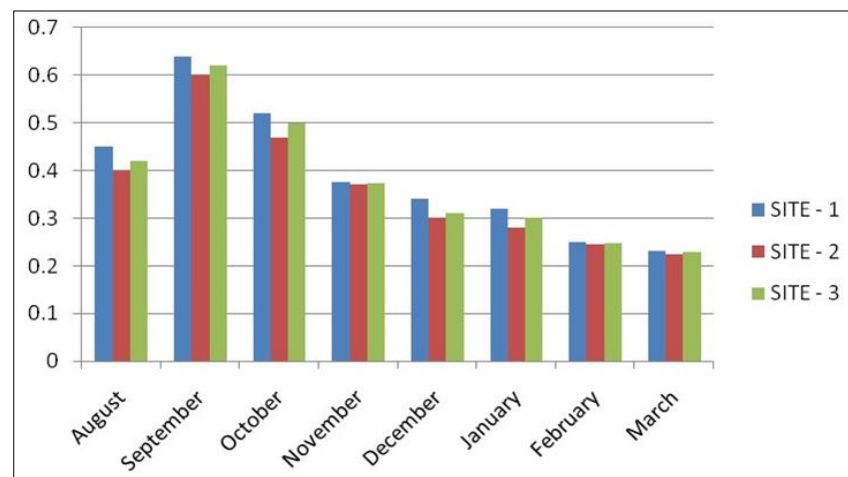

Fig 10: Monthly variation of Nitrate $\left(\mathrm{mg} \mathrm{L}^{-1}\right)$ at the selected sites of Nanak Sagar Reservoir

The most stable form of nitrogen is nitrate. Nitrates and nitrites are natural ions that are the part of nitrogen cycle. Nitrate ions are undesirable in drinking water because they can cause methemoglobinaemia in infants less than 6 months old ${ }^{[47]}$. The nitrate-nitrogen plays an important role in the biological productivity of the aquatic ecosystem.

\section{Conclusion}

The Nanak Sagar reservoir falls under the category of mesotrophic and water quality of the reservoir within normal conditions, so fish production from the reservoir could be increased by adopting culture-based fisheries and reducing intensive human activities. This study will support policy makers in developing a policy plan for the management of the Nanak Sagar reservoir.

\section{Acknowledgments}

The authors are grateful to G. B. Pant University of Agriculture and Technology authorities for providing facilities at the College of Fisheries, Pantnagar, to pursue the present study.

\section{References}

1. Sugunan VV. Reservoir Fisheries in India, FAO Fisheries Technical Paper No. 345, 1995, 423.

2. Anon EE. Irrigation Division Bareilly's, letter No. 1723, 1992.

3. Raveendar B, Sharma AP, Gurjar UR, Gugulothu R, Mishra A. Assessment the present status of fish diversity in relation to physicochemical characteristics of Nanaksagar reservoir of Uttrakhand. Journal of Entomology and Zoology Studies 2018a;6(2):477-484.

4. Banothu R, Sharma AP, Gurjar UR, Goswami K, Kumar $\mathrm{S}$, Tiwari H. Plankton diversity in relation to physicochemical characteristics of Nanak Sagar reservoir of Uttarakhand, India. Journal of Experimental Zoology, India 2018;21(2):1121-1129.

5. Raveendar B, Sharma AP, Gurjar UR, Takar S, Mishra A. Assessment the present fish catch composition from Nanak Sagar reservoir of Uttrakhand. Journal of Entomology and Zoology Studies 2018b;6(2):472-476.

6. Takar S, Dwivedi A, Gurjar UR, Saritha S, Jaiswar AK, Deshmukhe G. Spatio-temporal variation of zooplankton diversity in mangroves around Mumbai coast, Maharashtra. Journal of Entomology and Zoological Studies 2018;6(5):481-490.

7. Harikrishnan K, Sabu T, Sanil G, Paul M, Sathish M, Das MR. A Study on the distribution and ecology of phytoplankton in the Kuttanad wetland ecosystem, Kerala, India. Pollution Research 1999;18(3):261-269. 
8. Jhingran AG. Reservoir Fisheries in India. Journal of the Indian Fisheries Association 1988;18:261-273.

9. Natarajan AV. Ecology and state of fishery development in some man made reservoirs of India. In: Symposium on the development and utilization of inland fishery resources, Colombo, Sri Lanka. Indo Pacific Fish Comm 1976, 15.

10. Jhingran VG. Fish and Fisheries of India. Hindustan Publishing Corporation, India 1991, 1-727.

11. Potapova M, Charles DF. Distribution of benthic diatoms in US rivers in relation to conductivity and ionic composition. Freshwater biology 2003;48(8):1311-1328.

12. Sharma AP. Manual of fishery limnology. G.B. Pant University of Agric. \& Tech., Pantnagar 2000, 1-115.

13. APHA. Standard Methods for the Examination of Water and Wastewater. 22nd edition. Washington 2012, 1360.

14. Kaul V, Handoo. Studies on the ecology of Kashmir Himalaya. In JS. Singh and Brij Gopal (Eds) Perspective Ecology. Jagmander Book Agency, New Delhi 1989, 48.

15. Sengar PS, Das SK, Kumar S, Gogoi R, Behera S. Evaluation of soil quality of some Reservoir fisheries in Dhaulpur district of Rajasthan. International Journal of Fisheries and Aquatic Studies 2015;2(6):99-103.

16. Jhingran AG. Reservoir fisheries management in India. Bulletin Central Inland Capture Fisheries Research Institute 1989;45:1-65.

17. Golterman GE. Methods for chemical analysis of freshwater. IBP Hand Book 8, 1967, 188.

18. Schowoerbel J. Methods of Hydrobiology. Pergaman Press Ltd. Oxford, London 1972, 200.

19. Isyagi NA, Veverica KL, Asiimwe R, Daniels WH. Manual for the commercial pond production of the African catfish in Uganda. Kampala 2009, 222.

20. Verma R. Water and Fishery Resources of Kumaun Central Himalaya, India. Discovery 2013;8(19):7-12.

21. Nandkishor I, Ram RN, Nain AS, Kumar P. Study of Horizontal Zonation of Water Quality Characteristics and Productivity Status of Nanak Sagar Reservoir of Uttarakhand, India. Indian Journal of Ecology 2016;43(2):418-425.

22. Rawat HS. Studies on the Limnology and fisheries of Tumaria Reservoir. Ph.D. Thesis, Kumaun University, Nainital 1991, 188.

23. Mishra A, Chakraborty SK, Jaiswar AK, Sharma AP. Comparative Limnology and productivity of two medium Reservoirs of Uttarakhand, India. Environment and Ecology 2017;35(2C):1244-1251.

24. Deorari BP. Productive potential of a mamade reservoir of Tarai of Uttar Pradesh with particular reference to fish fauna. Ph.D. Thesis, Rohilkhand University, Bareilly 1993, 291.

25. Ananya BA, Sharma AP, Patra BC, Bera A, Manojit B, Roy C. Phytoplankton assemblage of Sarni Reservoir, Madhya Pradesh. American Research Thoughts 2016, 2(6).

26. Wetzel RG. Limnology: Lake and River Ecosystem. Academic Press, San Diego 2001, 1006.

27. Olsen S. Aquatic plants and hydrosheric factors I. aquatic plants in Swjutland, Denmark. Sevensk Botanisk Tidskriff 1950;44:1-34.

28. EPA. United States Environmental Protection Agency, Drinking water standards and health advisories, Washington D.C 2011.

29. Kaushik S, Saxena DN. Physico-chemical limnology of certain water bodies of Central India. In: Freshwater ecosystem of India. Daya Publication House 1999, 1-58.
30. Russel EW. Soil conditions and plant growth, 10th edn. Longman, London 1973, 151.

31. Takar S, Gurjar UR, Saroj J, Banothu R, Singh J, Deshmukhe G. Benthic organisms in mumbai mangroves: diversity and distribution in relation to environmental parameters. Journal of Experimental Zoology India 2020;23(1):599-605.

32. Das SM. Hydrogen Ion Concentration, Plankton and Fish in Fresh-water Eutrophic Lakes of India. Nature 1961;191(4787):511.

33. Mishra A, Srivastava A, Singh UP. Limnological studies of fish ponds in Tarai Region of Uttar Pradesh. Environment and Ecology 2003;21(3):623-627.

34. Sreenivasan A. Limnology and fisheries management. 5th FAO/ SIDA Workshop on Aquatic pollution in relation to protection of living resources. Scientific and administrative basis for management measures, Manila, Philippines 1977.

35. Vass KK, Sugunan VV. Status of Reservoir Fisheries in India: Status of reservoir fisheries in five Asian countries. (eds. By De Silva, S.S. and Amarasinghe, U.S.). NACA Monograph No.2, Network of Aquaculture Centres in Asia-Pacific, Bangkok, Thailand 2008, 113.

36. Hynes HBN. The biology of polluted waters. Livepool Univ. Press 1978, 202.

37. Yadava YS, Singh RK, Choudhury M, Kolekar V. Limnology and productivity of Dighali beel (Assam). Tropical Ecology 1987;28(2):137-146.

38. Smith SV, Hollibaugh JT. Annual cycle and interannual variability of ecosystem metabolism in a temperate climate embayment. Ecological Monographs 1997;67(4):509-533.

39. Hopkinson CS. Shallow-water benthic and pelagic metabolism: evidence of heterotrophy in the nearshore Georgia bight. Marine Biology 1985;87:19-32.

40. Naz M, Turkmen M. Phytoplankton biomass and species composition of Lake Golbasi (Hatay-Turkey). Turkish Journal of Biology 2005;29:49-56.

41. Krishnankutty N, Chandrasekaran S. Biodiversity hotspots: Defining the indefinable. Current Science 2007;92:1344-1345.

42. Patil RS, Sawant RS, Patil SR, Chougale SR. Water Quality of Dug Wells from Samangad Fort and Adjoining Area, Western Maharashtra, India. European Academic Research 2015;3(3):2893-2902.

43. Budhlani GN, Musaddia M, Khan J, Zabir N. Seasonal variation in physicochemical characteristics of Bor and Vidarbha rivers of Amravati (M.S), India. Indian Journal of Applied Research 2014;4(1):496-499.

44. Huchinson GE. A Treaties on Limnology-ii Introduction of lake biology and the Limnoplankton. J Wiley and Sons New York and London 1967, 115.

45. Gopalkrushna MH. Determination of Physico-Chemical parameters of surface water samples in and around Akot City. International Journal of Research in Chemistry and. Environment 2011;1:183-187.

46. Gordillo FJL, Ruiz RG, Corzo A, Lucena J, Niell FX. Nitrate Reductase Activity in an Eutrophic Reservoir duringthe Stratification Cycle. International Review of Hydrobiology: A Journal Covering all Aspects of Limnology and Marine Biology 2001;86(6):603-618.

47. Egereonu UU, Nwachukwu UL, Nwachukwu. Evaluation of the surface and Groundwater resources of Efuru river catchment, Mbano, South Eastern, Nigeria. J Assoc Adv Model Simulat Tech Enterpr 2005;66:53-71. 